\title{
Comparative Assessment of Women Involvement in Farming and Family Life in Rural Parts of Nigeria
}

\author{
L. O. Ogunsumi ${ }^{1}$, Victor A. Adeyeye ${ }^{2} \&$ F. B. Fato ${ }^{3}$ \\ ${ }^{1}$ Institute of Agricultural Research and Training, Obafemi Awolowo University, Ibadan, Nigeria \\ ${ }^{2}$ Nigerian Institute of Social and Economic Research, Ibadan, Nigeria \\ ${ }^{3}$ Federal College of Agriculture, Ibadan, Nigeria \\ Correspondence: L. O. Ogunsumi, Institute of Agricultural Research and Training, Obafemi Awolowo University, \\ Ibadan, Nigeria. Tel: 234-803-717-3993. E-mail: lucyogunsumi2011@gmail.com
}

Received: March 1, 2017

Accepted: July 9, 2017 Online Published: August 15, 2017

doi:10.5539/jas.v9n9p201

URL: https://doi.org/10.5539/jas.v9n9p201

\begin{abstract}
The study was carried out through the use of structured questionnaire administered on women in two agricultural zones of Oyo State. The main objective of this paper is to examine the extent of women's participation in farming specifically, the paper is designed to identify the sources of income and compare income levels in two geographical settings, identify and compare farming activities in two different farming zones. In the paper attempt has been made to characterize the farm labour force, access to land and other inputs in the two different farming zones and on the basis of all these some recommendations that if implemented would lead to increase in output, increase in return from farm and consequently increase in their various contributions to the household have been proposed.

Some fifty women were interviewed from the two selected zones. Descriptive statistics was used to explain the background information, socio economic activities farming activities, development projects, as well as the problems encountered by women in the two areas.

Multiple regression analysis was used to show the extent to which variables such as age, hectarage, educational attainment and experience in farming affect the income of rural women in the study areas. Dummy variables were added to distinguish between the two areas. This is to show if there was a significant difference in the income levels of the rural women in the areas.

The study revealed that the size of the farmland cultivated by women in the two areas was generally small. About 50 percent of the respondents cultivated one hectare of land or below. Low credit facility for farm work and lack of modern inputs like fertilizer and improved seeds were major constraints for increased productivity among the women respondents. Innovations introduced in the study areas include Adult education, improved seeds coupled with improved production package. The $\mathrm{t}$-test revealed the lead equation being semi-log, the coefficients of which are hectarage cultivated, educational level and income from other sources were significant at 95 percent confidence level. About, 59 percent of the variations in the income of rural women interviewed were explained by the independent variables.
\end{abstract}

Keywords: assessment, women, involvement, family life

\section{Introduction}

The increasing importance of women in the general development process of an economy can no longer be brushed aside. Women grow, process, market, store and prepare food for both home consumption and commercial purposes (Muller, 1978; Adeyeye, 1996; Ogunsumi, 2004). Through these means they earn income and are able to care for their children and other family members. Thus, they could be considered as been active both in community and family life.

Since 1957 when increased attention was given to women through the declaration of international women's year the role of women in food production has come to the limelight, and it has been acknowledged that women perform most of the household work in addition to other agricultural works. In Nigeria, rural women engage in activities varying from food production to food processing in addition to marketing. According to Pearson (1996), 
women also assist in most activities even if they are not the main person carrying out the task and they undertake much of the labour and time consuming crop production activities. Studies undertake in Africa indicated that most rural women pursue marketing activities as their primary means of obtaining cash income (Ogunsumi, 2010). Women participation in market is greatest when traditional trade is practiced.

So, there are strong indications that women are partners in a typical family. In the light of this, the main objectives of this paper are to examine the extent of women's participation in farming. Specifically, the paper is designed to; identify the sources of income and compare income levels in the two geographical settings: identify and compare farming activities in two different farming zones: characterize the farm labour force, access to land and other farm inputs and consequently increase in their various contributions to the household.

The relevance of this paper is based on the need to ascertain factors that affect the extent of women's participation in farming and family life, thus helping policy makers to know how best to fashion out modalities for improving women's participation in farming and contributions to family living.

A lot of studies have been carried out on the economic role of women in agriculture and other development aspects. However, little thought has so far been given to the fact that women are not homogenous set of people, even within the same household, talk-less of varying geographical settings.

Boserup (1970), described Africa's South of the Sahara as "the region of female farming per excellence". In a study of women and agriculture in Nigeria, Adeyokunnu (1980), found that some women considered farming as their major creation. Adeyokunnu's sample consisting of 400 women was drawn from three different parts of Nigeria: Odo-Otin in old Oyo state, Northern Nigeria (Hausa/Fulani), forty percent of the sample considered farming as their major occupation, the largest being in the Eastern sub-sample, followed by the West and the least the North. She further noted that women farmers undertake most of the farm operations themselves. They cultivate mainly food crops such as maize, rice, guinea corn, millet, yam, and cassava for home consumption and sales (Ogunsumi et al., 2013).

To Osuntogun (1976), and Sipro (1977), Yoruba women plant, weed and harvest crop like maize, cassava, yam, and they grow vegetables for family consumption. Their work on various cash crops owned by men is remunerated and many is compensated in kind or with cash for services rendered throughout the season. Similar observation was noted by (Jackson, 1992).

Similarly, Afonja (1984) observed Tiv women to be agriculturally active, planting, weeding, harvesting, and processing what is grown (millet, legumes, cassava, maize, yam, etc.) for family consumption and selling the surpluses. It is strange therefore, that most project planners do not consider the fact that women are not a homogenous interest group even within the same household and tribe.

Den Quden (1980) in his research concluded that due to increased land scarcity and commercialization women are not allowed to cultivate land. He also said commercialization of vegetable crops have helped women grow financially stronger in areas where they have access to land.

Roger (1981) observed that women work 10-16 hours a day in comparison with 10 working hours of men.

Bryson (1979) opined that marriage and divorce rules are disincentives to women to make long term investment in farming. He further said that since women have other responsibilities in the household beyond food production the area they cultivate is smaller than that of males. However, most women are able to meet the nutritional needs of their family through their own production and also have surplus to sell.

An important issue, which has often been ignored in recent times, is women's participation in agricultural decision- making at the household level (Jackson, 1992). David Hirschumann and Vangan (1984) studied women in Zambo region/district of Malawi. They took sample in 54 villages and interviewed seventy women. They observed in their analysis that women dominate fifty-one percent of decisions. Most women farmer has firm control over their agricultural production and sales even in the household where their husbands were present. They decide on their own which crop to grow, employment of labour, marketing of their farm produce and purchase of household needs. Men on the other hand take decisions on matters involving cash outlays, buying fertilizers, asking for credits and sometimes employment of labour particularly on their own farms. From this literature review one can conclude that women have much to contribute to farming activities especially in the area of food production. Their contributions to family welfare and food security are also of importance in family life. Indeed, women are farmers in their own right. 


\section{Methodology}

For the data collected in this study, structured questionnaires were administered on women in two Agricultural zones. Also existing literature relevant to the study were used. The two study areas used were Lerin-Ode village in Odeda Local Government Area of Ogun State and Fajoye village in Oluyole Local Government Area Oyo State.

Lerin-Ode village: This village is situated in the Northern part of Odeda Local Government Area. Odeda on the other hand is located in the northern part of OgunState. Agriculture is the main economic activity in the village. Most of the food crops grown are mainly for household needs, while very few people grew palm trees and kola-nut. Land may be owned or leased. Farming activities are intensive and are done with crude and energy sapping implement such as hoes and cutlasses. In addition to agriculture, many people especially women engage in trading and food processing. In this paper, this village is assumed as village 1.

Fajoye village: This village is in Oluyole Local Government Area of Oyo State. The Local Government Area lies in southeast of the State. Agriculture is the main economic occupation in Fajoye. Food crops grown in this village are mainly consumed but appreciably large quantities are brought down to Ibadan for sale. The crops mainly grown are yam and cassava and very few people grow palm trees. Land may also be bought or leased in this area. In the paper, Fajoye village, in Oluyole Local Government Area is assumed village 2.

Lerin-Ode and Fajoye are in OgunState (Egba tribe) and OyoState (Oyo tribe) respectively with some what different socio-economic and cultural practices. The choice of these two villages was, therefore, purposive in order to capture effect of culture on women performance in farming and family life.

On the other hand, the use of statistical analysis involved, multiple regression in which age, hectrage, educational attainment, experience in farming, family size and income from other sources were regressed, on the total income of women farmers in two sample zones. This was to show the extent to which these variables affect the income of rural women in the areas. The model used was to show the extent to which these variables affect the income of rural women in the areas. The model used was $Y=f\left(X_{1} X_{2} X_{3} X_{4} X_{5} X_{6}\right)$, where, $X_{1} X_{2} X_{3} X_{4} X_{5} X_{6}$ represented age, hectrage, educational attainment, experience in farming, size and income from other sources respectively; Y represented total income of rural women. The two data from the different zones was combined and regressed. Dummy variable were used to distinguish between the two zones. One area had a dummy variable of 1 and the other 0 .

\section{Result and Discussion}

\subsection{Results}

In Odeda LGA, 4 percent of the women interviewed were under the age 20 years, 56 percent were between 21-40 years, 32 percent between 41-60 years, while 81 percent were above the age of 61 years. In Oluyole Local Government area, none of the women interviewed was under the age of 20 years while 52 percent of the ages of 41-60 years. Most of them were between the ages of 21-40 years of them in the two areas fell within the productive age range.

In Odeda LGA 76 percent of the women farmers interviewed had any education, 24 percent of them attended only primary school, whereas in Oluyole LGA, 92 percent of the women farmers interviewed have never had any education, while only 8 percent of them attended only primary school. The high degree of illiteracy in the two areas might have contributed to the use of crude and labour intensive farm implements like cutlass, hoes and very low use of fertilizer resulted in low farm output. 
Table 1. Distribution of respondent by crops grown

\begin{tabular}{|c|c|c|c|c|c|c|}
\hline \multirow{2}{*}{ Crops } & \multicolumn{2}{|c|}{ Area 1} & \multicolumn{2}{|c|}{ Area 2} & \multicolumn{2}{|c|}{ Area 3} \\
\hline & No. & $\%$ & No. & $\%$ & No. & $\%$ \\
\hline Maize & 22 & 88 & 8 & 12 & 30 & 10 \\
\hline Rice & 0 & 0 & 0 & 0 & 0 & 0 \\
\hline Yam & 1 & 12 & 4 & 4 & 4 & 8 \\
\hline Cassava & 23 & 92 & 32 & 31 & 41 & 62 \\
\hline Guinea Corn & 0 & 0 & 0 & 0 & 0 & 0 \\
\hline Millet & 2 & 5 & 0 & 2 & 2 & 4 \\
\hline Cocoa & 0 & 0 & 0 & 0 & 0 & 0 \\
\hline Oil Palm & 1 & 4 & 4 & 2 & 2 & 4 \\
\hline Kolanut & 2 & 4 & 0 & 0 & 1 & 2 \\
\hline Soya bean & 0 & 0 & 0 & 0 & 0 & 0 \\
\hline
\end{tabular}

About 80 percent of the respondents in Odeda Local Government area cultivated one hectare of land or below. About 8 percent of the respondents cultivated between 1-2 hectares of land while 4 percent of them cultivated between 2-3 hectares of land.

About 44 percent of the women obtained land by lease in Odeda LGA. On the other hand, in Oluyole LGA most and 56 percent of women farmers who purchased their land, 4 percent used their own family land, 16 percent obtained land by lease and about 24 percent used their husband's land.

Table 2. Farm operation and source of labour

\begin{tabular}{|c|c|c|c|c|c|c|c|c|c|c|c|c|}
\hline & \multicolumn{4}{|c|}{ Own Labour } & \multicolumn{4}{|c|}{ Members of Family } & \multicolumn{4}{|c|}{ Hired Labour } \\
\hline & \multicolumn{2}{|c|}{ Area 1} & \multicolumn{2}{|c|}{ Area 2} & \multicolumn{2}{|c|}{ Area 1} & \multicolumn{2}{|c|}{ Area 2} & \multicolumn{2}{|c|}{ Area 1} & \multicolumn{2}{|c|}{ Area 2} \\
\hline & No. & $\%$ & No. & $\%$ & No. & $\%$ & No. & $\%$ & No. & $\%$ & No. & $\%$ \\
\hline Initial clearing & 0 & 0 & 1 & 4 & 0 & 0 & 0 & 0 & 22 & 88 & 10 & 40 \\
\hline Planting & 10 & 40 & 7 & 28 & 4 & 16 & 1 & 4 & 2 & 8 & 2 & 8 \\
\hline Weeding & 2 & 8 & 3 & 12 & 0 & 0 & 0 & 0 & 17 & 68 & 5 & 20 \\
\hline Staking plant & 8 & 32 & 3 & 12 & 0 & 0 & 0 & 0 & 0 & 0 & 1 & 4 \\
\hline \multicolumn{13}{|l|}{ Fertilizer } \\
\hline Application & 1 & 4 & 1 & 4 & 0 & 1 & 1 & 4 & 0 & 0 & 0 & 0 \\
\hline Spraying & 0 & 0 & 0 & 0 & 0 & 0 & 0 & 0 & 0 & 0 & 0 & 0 \\
\hline Harvesting & 18 & 72 & 8 & 32 & 1 & 4 & 0 & 0 & 3 & 12 & 3 & 12 \\
\hline Processing & 17 & 68 & 5 & 20 & 2 & 8 & 0 & 0 & 4 & 16 & 1 & 4 \\
\hline Sales & 19 & 76 & 6 & 24 & 0 & 0 & 0 & 0 & 0 & 0 & 1 & 4 \\
\hline
\end{tabular}

As mush as 92 percent of the woman in Odeda Local Government ascertained that their functions was to given financial support to members of associations they belong to. In the same areas only 8 percent of the respondents did not belong to any associations. In Oluyole LGA, 52 percent of the respondents belonged to women's group which will also offered assistance to members. In Odeda LGA, 88 percent of the respondents indicated the lack of modern farm inputs as problem, 42 percent of them indicated low credit facility as a problem. In Oluyole LGA, 16 percent saw low credit as their problem. Also, 24 percent indicated lack of improved farm inputs as problems.

As shown in Table 4, on the whole, 20 percent of the believed that women are taken along in the development process. 
Table 3. Extension of involvement of women in new practices

\begin{tabular}{|c|c|c|c|c|c|c|}
\hline & \multicolumn{2}{|c|}{ Area 1} & \multicolumn{2}{|c|}{ Area 2} & \multicolumn{2}{|c|}{ Areas $1 \& 2$} \\
\hline & Number & $\%$ & Number & $\%$ & Number & $\%$ \\
\hline Consulted before introduction & 23 & 92 & 14 & 56 & 37 & 74 \\
\hline Not consulted & 1 & 4 & 5 & 20 & 6 & 12 \\
\hline Instructed on it's application & 23 & 72 & 6 & 24 & 29 & 58 \\
\hline Not instructed & 1 & 4 & 5 & 20 & 6 & 12 \\
\hline Involved in implementation activity & 23 & 92 & 3 & 12 & 26 & 52 \\
\hline Not actively involved & 1 & 4 & 8 & 32 & 9 & 18 \\
\hline
\end{tabular}

Table 4. Response to whether women were by-passed in development

\begin{tabular}{|c|c|c|c|c|c|c|}
\hline & \multicolumn{2}{|c|}{ Area 1} & \multicolumn{2}{|c|}{ Area 2} & \multicolumn{2}{|c|}{ Areas $1 \& 2$} \\
\hline & Number & $\%$ & Number & $\%$ & Number & $\%$ \\
\hline Yes & 2 & 8 & 8 & 32 & 10 & 20 \\
\hline No & 23 & 92 & 17 & 68 & 40 & 80 \\
\hline
\end{tabular}

Table 5. Results of regression analysis for Odeda and Oluyole Local Government

\begin{tabular}{|c|c|c|c|c|c|c|c|c|c|c|}
\hline Functional Farms & Constant term & Age $X_{1}$ & $\begin{array}{l}\text { Hectarage } \\
\mathrm{X}_{2}\end{array}$ & $\begin{array}{l}\text { Education } \\
\mathrm{X}_{3}\end{array}$ & $\begin{array}{l}\text { Experience } \\
\mathrm{X}_{4}\end{array}$ & $\begin{array}{l}\text { Family Size } \\
\mathrm{X}_{5}\end{array}$ & $\begin{array}{l}\text { Income from } \\
\text { other sources } \mathrm{X}_{6}\end{array}$ & Dummy D & $\mathrm{R}^{3}$ & F-Ratio \\
\hline Linear & & & $\mathrm{a}, \mathrm{b}$ & $a, b$ & & & $a, b$ & & & \\
\hline & 1.23856 & $\begin{array}{l}0.14816 \\
(0.19733)\end{array}$ & $\begin{array}{l}0.57849 \\
(0.08781)\end{array}$ & 0.98552 & $\begin{array}{l}0.06077 \\
0.11242\end{array}$ & $\begin{array}{l}0.09684 \\
(0.27993)\end{array}$ & $\begin{array}{l}0.70870 \\
(0.10137)\end{array}$ & $\begin{array}{l}-0.52947 \\
(0.65220)\end{array}$ & 0.82523 & 28.33053 \\
\hline Semi log & & & $\mathrm{a}, \mathrm{b}$ & & $\mathrm{a}, \mathrm{b}$ & & a,b & & & \\
\hline & -0.12271 & $\begin{array}{l}3,49723 \\
(2.14438)\end{array}$ & $\begin{array}{l}4,69233 \\
(0.70031)\end{array}$ & $\begin{array}{l}2,54799 \\
(0.53368)\end{array}$ & $\begin{array}{l}-2.07741 \\
(0.88112)\end{array}$ & $\begin{array}{l}1.06892 \\
(1,39215)\end{array}$ & $\begin{array}{l}6.77838 \\
(0.9833)\end{array}$ & -0.20984 & 0.82249 & 27.80021 \\
\hline Double log & 0.00553 & $\begin{array}{l}0.41103 \\
(0.24725)\end{array}$ & $\begin{array}{l}a, b \\
0.48208 \\
(0.08144)\end{array}$ & $\begin{array}{l}0.07745 \\
(0.52274)\end{array}$ & -0.15669 & $\begin{array}{l}\mathrm{b} \\
0.3061\end{array}$ & $\begin{array}{l}a, b \\
0.64905 \\
(0.11338)\end{array}$ & 0.02178 & 0.77616 & \\
\hline Exponential & 0.17443 & $\begin{array}{l}0.01495 \\
(0.02482)\end{array}$ & $\begin{array}{l}a, b \\
0.05793 \\
(0.01105)\end{array}$ & $\begin{array}{l}\text { a,b } \\
0.11704 \\
0.18351\end{array}$ & $\begin{array}{l}0.00532 \\
(0.0352)\end{array}$ & $\begin{array}{l}0.0384 \\
(0.0352)\end{array}$ & $\begin{array}{l}\mathrm{a}, \mathrm{b} \\
0.08424 \\
(0.01275)\end{array}$ & $\begin{array}{l}-0.05566 \\
(0.08204)\end{array}$ & 0.73768 & 16.81234 \\
\hline Square root & 0.69326 & $\begin{array}{l}0.22933 \\
(0.023892)\end{array}$ & $\begin{array}{l}0.34562 \\
(0.066691)\end{array}$ & $\begin{array}{l}0.18351 \\
(0.13908)\end{array}$ & $\begin{array}{l}0.13300 \\
(0.08725)\end{array}$ & $\begin{array}{l}0.10187 \\
(0.12858)\end{array}$ & $\begin{array}{l}0.55538 \\
(0.09944)\end{array}$ & $\begin{array}{l}0.01096 \\
(0.21866)\end{array}$ & 0.74988 & 17.58809 \\
\hline
\end{tabular}

Table 6. Results of regression analysis for Odeda Local Government Area

\begin{tabular}{|c|c|c|c|c|c|c|c|c|c|}
\hline Functional Farms & Constant term & Age $X_{1}$ & $\begin{array}{l}\text { Hectarage } \\
\mathrm{X}_{2}\end{array}$ & $\begin{array}{l}\text { Education } \\
\mathrm{X}_{3}\end{array}$ & $\begin{array}{l}\text { Experience } \\
\mathrm{X}_{4}\end{array}$ & $\begin{array}{l}\text { Family Size } \\
\mathrm{X}_{5}\end{array}$ & $\begin{array}{l}\text { Income from } \\
\text { other sources } \mathrm{X}_{6}\end{array}$ & $\mathrm{R}_{2}$ & F-Ratio \\
\hline \multirow[t]{3}{*}{ Linear } & & & $\mathrm{a}, \mathrm{b}$ & $\mathrm{a}, \mathrm{b}$ & -0.01267 & 0.17619 & $\mathrm{a}, \mathrm{b}$ & & \\
\hline & 1.53472 & -0.10247 & 0.6481 & 1.22534 & $(0.14673)$ & $(0.123197)$ & 2.50556 & 0.75635 & 9.31259 \\
\hline & & 0.19003 & $(0.14398)$ & $(0.44762)$ & 0.11242 & $(0.27993)$ & $(0.10137)$ & & \\
\hline \multicolumn{10}{|l|}{ Semi log } \\
\hline & 1.99290 & 0.18854 & 4,53441 & 0.0 & -1.84815 & 1.03807 & 0.0 & 0.58732 & 4,2695 \\
\hline & & $(2.23786)$ & $(1.03059)$ & $(0.22254)$ & $(1.05791)$ & $(1.80460)$ & $(0.22254)$ & & \\
\hline \multirow[t]{3}{*}{ Double log } & & & $\mathrm{a}, \mathrm{b}$ & & & & & & \\
\hline & 0.13438 & 0.15459 & 0.58862 & 0.0 & -184050 & 0.37256 & 0.0 & 0.57177 & 4.00564 \\
\hline & & $(0.41024)$ & & $(0.03217)$ & $(0.15293)$ & $(0.28087)$ & $(0.03217)$ & & \\
\hline \multirow[t]{3}{*}{ Exponential } & & & $\mathrm{a}, \mathrm{b}$ & $\mathrm{a}, \mathrm{b}$ & & & $\mathrm{a}, \mathrm{b}$ & & \\
\hline & 0.11304 & -0.0248 & 0.08040 & 0.15852 & 0.01489 & 0.07507 & 0.40397 & 0.89141 & 6,72159 \\
\hline & & $(0.03035)$ & $(0.02299)$ & $(0.07147)$ & $(0.02343)$ & $(0.06737)$ & $(0.18958)$ & & \\
\hline \multirow[t]{3}{*}{ Square root } & & & $a, b$ & $a, b$ & & & $\mathrm{~b}$ & & \\
\hline & 1,27909 & -0.22634 & 0.37634 & 0.34822 & -0.02706 & 0.26593 & $(0.55767)$ & 0.68190 & 6,43086 \\
\hline & & $(0.28700)$ & $(0.11319)$ & $(0.13963)$ & $(0.10121)$ & $(0.30686)$ & & & \\
\hline
\end{tabular}


Table 7. Results of regression analysis for Oluyole Local Government Area

\begin{tabular}{|c|c|c|c|c|c|c|c|c|c|}
\hline Functional Farms & Constant term & Age $X_{1}$ & $\begin{array}{l}\text { Hectarage } \\
\mathrm{X}_{2}\end{array}$ & $\begin{array}{l}\text { Education } \\
\mathrm{X}_{3}\end{array}$ & $\begin{array}{l}\text { Experience } \\
\mathrm{X}_{4}\end{array}$ & $\begin{array}{l}\text { Family Size } \\
\mathrm{X}_{5}\end{array}$ & $\begin{array}{l}\text { Income from } \\
\text { other sources } \mathrm{X}_{6}\end{array}$ & $\mathrm{R}_{2}$ & F-Ratio \\
\hline \multicolumn{10}{|l|}{ Linear } \\
\hline & 0.19770 & $\begin{array}{l}0.40312 \\
(0.37610)\end{array}$ & $\begin{array}{l}0.53844 \\
(0.12842)\end{array}$ & $\begin{array}{l}0.84665 \\
(0.81360)\end{array}$ & $\begin{array}{l}-0.18408 \\
(0.18559)\end{array}$ & 0.07314 & $\begin{array}{l}0.74517 \\
(0.13981)\end{array}$ & 072296 & 7.82895 \\
\hline Semi log & & $\mathrm{b}$ & $a, b$ & & & & $a, b$ & & \\
\hline & -1.76571 & $\begin{array}{l}6.11611 \\
(3.4877)\end{array}$ & $\begin{array}{l}4,79305 \\
(1.06100)\end{array}$ & $\begin{array}{l}4,04069 \\
(5.67788)\end{array}$ & $\begin{array}{l}-2.48529 \\
(1.56064)\end{array}$ & $\begin{array}{l}0.60788 \\
(2,19534)\end{array}$ & $\begin{array}{l}7.31005 \\
(1,36639)\end{array}$ & 0.75211 & 9.102214 \\
\hline \multirow[t]{2}{*}{ Double log } & & & $\mathrm{a}, \mathrm{b}$ & & & & $\mathrm{a}, \mathrm{b}$ & & \\
\hline & 40.14683 & $\begin{array}{l}0.65154 \\
(0.32598)\end{array}$ & $\begin{array}{l}0.33812 \\
(0.69917)\end{array}$ & $\begin{array}{l}0.28304 \\
(0.53058)\end{array}$ & $\begin{array}{l}-0.23203 \\
(0.14586)\end{array}$ & $\begin{array}{l}0.14731 \\
(0.20519)\end{array}$ & $\begin{array}{l}0.74606 \\
(0.12721)\end{array}$ & 0.78635 & 10.65789 \\
\hline \multirow[t]{2}{*}{ Exponential } & & & $a, b$ & & & & $a, b$ & & \\
\hline & 0.08447 & $\begin{array}{l}0.04414 \\
(0.37546)\end{array}$ & $\begin{array}{l}0.04785 \\
(0.05536)\end{array}$ & $\begin{array}{l}0.07935 \\
(0.25020)\end{array}$ & $\begin{array}{l}0.00842 \\
(0.63805)\end{array}$ & $\begin{array}{l}0.02411 \\
(0.15950)\end{array}$ & $\begin{array}{l}0.0758 \\
(0.12600)\end{array}$ & 0.69050 & 6.69310 \\
\hline Square root & 0.15839 & $\begin{array}{l}0.53642 \\
(0.37546)\end{array}$ & $\begin{array}{l}a, b \\
0.04785 \\
(0.05536)\end{array}$ & $\begin{array}{l}-608410 \\
(0.25020) \\
(0.25020)\end{array}$ & $\begin{array}{l}b \\
-626863 \\
(0.13805)\end{array}$ & $\begin{array}{l}0.041502 \\
(0.15950)\end{array}$ & $\begin{array}{l}\text { a.b } \\
0.65595 \\
(0.121600)\end{array}$ & 0.69219 & 6.94632 \\
\hline
\end{tabular}

From the t-test of the lead equation, the coefficient of $X_{2}, X_{3}, X_{6}$ are significant at 5 percent level of significance and this shows that income of rural women in Odeda LGA was largely determined by hectarage cultivated, educational level and income from other sources. The coefficient of $\mathrm{X}_{1}, \mathrm{X}_{4}$, and $\mathrm{X}_{5}$ are not significant at 5 percent level of significance. The lead equation is written as:

$\mathrm{Y}=1.96574+6.11611 \log \mathrm{X}_{1}+4.79305 \log \mathrm{X}_{2}+4.04060 \log \mathrm{X}_{3}-2.48529 \log \mathrm{X}_{4}+0.060788 \log \mathrm{X}_{5}+7.31005 \log \mathrm{X}_{6}$

$$
\begin{array}{lllll}
(3.48771) & (1.06100) & (5.67788) & (1.56064)
\end{array}
$$

$\mathrm{R}^{2}=0.75211$

From the t-test of the lead equation, the coefficient of $X_{1}, X_{2}, X_{6}$ are found to be significant at 10 percent level of significance.

\subsection{Statistical Analysis of Data}

Table 5 and 6 shows the five functional forms fitted in the regression analysis for Odeda LGA in OgunState and Oluyole in OyoState respectively based on the criteria for choosing lead equation (i.e. higher $\mathrm{R}^{2}$ values, number of significant variables, etc.) linear equation had the higher magnitude of the coefficient of multiple determination. Hence, it is chosen as the lead equation. The lead equation is written as:

$$
\begin{aligned}
& \mathrm{Y}=1.53492-0.10247 \mathrm{X}_{1}+0.64681 \mathrm{X}_{2}+1.2253 \mathrm{X}_{3}+0.17619 \mathrm{X}_{4}+0.01267 \mathrm{X}_{5}+0.50556 \mathrm{X}_{6} \\
& \begin{array}{llllll}
(0.19003) & (0.14398) & (0.44762) & (0.14673) & (0.42197) & (1.18704)
\end{array}
\end{aligned}
$$

$\mathrm{R}^{2}=0.75635$

Tables 5, 6, and 7 show the 5 functional forms fitted in regression analysis for the two LGAs with dummy variables to distinguish them and hence was chosen as lead equation.

The lead equation is written as:

$$
\begin{aligned}
& Y=1.23956+0.14816 X_{1}+0.57849 X_{2}+0.98592 X_{3}-0.06077 X_{4}+0.07684 X_{5}+0.70870 X_{6}-0.529470 \\
& \begin{array}{lllllll}
(0.19733) & (0.08781) & (0.44580) & (0.11243) & (0.27993) & (0.10139) & (0.65220
\end{array}
\end{aligned}
$$

$\mathrm{R}^{2}=0.82523$

From the t-test of the lead equation in Tables 6 and 7, the coefficient of dummy variables was fouud to be significant at 10 percent level of significance. This implies that income of rural women in Odeda LGA and Oluyole LGA were not statistically significantly different from each other.

\subsection{Discussion}

In Odeda LGA, 60 percent of the respondents have between 1 and 3 children. About 36 percent of them have between 4 to 6 children while the rest respondents in this area did not disclose the number of their children because it is a taboo for them to do so. In Oluyole Local Government area, 56 percent of the respondents have between 1 and 3 children, about 28 percent of them have between 4 and 6 children while the remaining respondents did not disclose the number of their children and also said it was a taboo. 
The size of the farm land cultivated by women in the two areas was generally low, and this might have been caused by their high use of crude farm implement and other energy and time consuming house chores like cleaning of the house, washing and child caring. Relatively more farmland was cultivated in Odeda Local Government Area than in Oluyole Local Government Area.

Few woman farmers in Odeda LGA used traditional inputs and simple hand tools. Most respondents engaged in the use of non-traditional farm inputs like fertilizer, agrochemical, simple hand tools and tractor in Oluyole LGA. The level of technology was generally low in the two areas surveyed probably due to illiteracy, inaccessibility of improved technical knowhow.

This financial help improved their income generating potential and consequently higher food crop production. This financial help improved their income generating potential and consequently higher food crop production. Generally, low credit facility for farm work and lack of use of modern farm inputs like fertilizer, improved seeds tractor, etc. were the major problems encountered by the respondent. New practices have been recently introduced in the areas by officers from the community development officers of the various LGA. The new practices recently introduced were adult education, fertilizer, hybrid seed and extension education. In Odeda LGA, adult literacy was the only new practices hybrid seed were introduced in Oluyole LGA.

The results from the analysis indicate that income of rural women in Odeda LGA was not really determined by their age experience in farming and family size. On the other hand, Table 6 shows functional forms fitted in a regression analysis for Oluyole LGA of Oyo State and based on the criteria for choosing a lead equation, semi $\log$ function had the highest magnitude of the coefficient of multiple determinations $\mathrm{R}^{2}$, hence it was chosen as the lead equation. From the $t$-test of the lead equation, the coefficient of $X_{1}, X_{2}, X_{6}$ are found to be significant at 10 percent level of significance. This implies that age, hecterage and income from other source, contributed largely to the income of rural women in Oluyole LGA.

That the coefficient of $\mathrm{X}_{3}, \mathrm{X}_{4}, \mathrm{X}_{6}$ were not significant at 10 percent level of significance implies that though they contributed to the variation in income, their effect were very minimal to the extent that they could not influence the income of rural women if taken individually. Tables 5, 6 and 7 show the 5 functional forms fitted in regression analysis for the two LGAs with dummy variables to distinguish them. Based on the criteria for choosing a lead equation, linear function had the highest magnitude of the coefficient of multiple determination $\mathrm{R}^{2}$ and hence was chosen as lead equation.

\section{Recommendation and Conclusion}

In this paper, attempt has been made to characterize involvement of women in farming and family, and the consideration such involvement have for rural development. The observations and deductions in the paper are drawn from empirical work carried out in Odeda and Oluyole Local Government Areas of Ogun and Oyo States respectively. Age distribution of the respondents in the two different zones was practically even having most of them within the productive age bracket (20-65 years). Out of all the respondents, only 12 percent of them in Oluyole were widowed. The literacy level was generally low in both zones but Oluyole has a slightly higher number of literate than Odeda.

In Odeda, more land was allocated to farming than in Oluyole. On the other hand, most of the land used were gotten from the same source in both zones i.e. husbands' land or by lease. The women farmers in Odeda LGA were much more directly involved in farm work than in Oluyole.

Furthermore, improved farm inputs were used more in Oluyole LGA. Respondents in Odeda LGA belonged to women's group. This made it easier for the women in Odeda to have more financial assistance to carry out their farm works than women farmers in Oluyole LGA. Generally, lack of improved farm inputs and easy credit facilities was responsible for a greater part of the problem encountered by the women farmers. On the development project, the two zones have introduced practices such as adult education, extension services and improved inputs.

The use of regression analysis enabled one to compare the relationship between the women farmers' income and their age, level of education, experience, income from other sources, family size, and hectarage. In Odeda, there was a positive correlation between women income and hectarage, level of education, family size, income from other sources, and experience but their income was negatively correlated with their age. Dummy variable were used to distinguish between the two communities and the coefficient of the dummy variable were found to be insignificant, which shows that women of the two local governments belonged to the same population of women farmers and therefore behave alike. 
A major conclusion which is also a recommendation in this study is that more rural women farmers require more attention in terms of good technologies for farming. Taking into consideration the labour intensive and low returns of women farmers, their working condition should be improved in terms of health and credit facilities. So, rural women should be encouraged with targeted programmes especially in the areas of improved inputs, extension and liberal credits.

Finally, the general aim of assisting rural women though training programme is to achieve self-sufficiency in food production, increase in cash income and rural development. All these strategies should be intensified. The conclusion therefore, is that if women are given appropriate type of technology to cater for their labour intensive farm activities; good financial assistance and favourable agricultural policies, they would not only increase agricultural production but also help in rural development through effective participation in attracting income to rural household. Their contribution to household food security and their potential to escape from poverty will also be enhanced.

\section{References}

Adeyeye, V. A. (1980). Women in Traditional Agriculture (M.Sc., Thesis, Department of Agricultural Economics, University of Ibadan, Ibadan).

Adeyokunnu, T. O. (1980). Women and Agriculture in Nigeria. Commissioned Study, University of Ibadan, Ibadan.

Angba, A. O. (2000). Determinant of Sustained Use of Selected Technologies Recommended to Farmers by Cross River State Agricultural Development Programme (ADP) (Unpublished Ph.D Thesis, University of Ibada, Nigeria).

Federal Office Statistics (FOS). (1998). Annual Abstract of Statistics. Lagos

Afonja, V. (1984). The Historical Evaluation of the Second Division of Labour in Nigeria. Paper Presented at the Meeting of Experts on The practical Frame-Work and Methodolical Approaches to Political Studies on the Role of Women as Actors in Economics, Social and Ideological processes, University of Ibadan, Ibadan.

Baumann, E. (1928). The Division of Works According to Sex in Africa. Hoe Culture, Africa, 1(3), $289-317$. https://doi.org/10.2307/1155633

Boserup, E. (1990). Women in Economic Development in Cameroon. World Bank, Washington, D.C. USA.

Bryson, J. C. (1975). Kano Irrigation Project. Personal discusson.

Cecilia, J. C. (1975). Kano Irrigation Project. Personnal discussion.

FAO. (1983). Women, Food and Nutrition. Africa Economic Change and the Outlook for Nutrition (pp. 671-679). FAO, Rome.

Hreshmann, D., \& Vaughan, M. (1980). Women Farmers of Malam Malawi. Food Production in Zambia District. Institute of International Studies, University of California Berkeley, USA.

Jackson, L. (1992). Gender, Women and Environment: Harmony or Discord Discussion Paper (pp. 1-25). GAIDS School of Development Studies, University of East Anglis.

Kaberry, P. M. (1952). Women of the Grass Fields: A Case Study of the Position of Women in Bamada (pp. 1-30). British Cameroon, London H.M.S.C. Colonial Research Publication.

Ogunsumi, L. O. (2004). Analysis of Sustained use of Agricultural Technologies on Farmers' Productivity in Southwest, Nigeria (Ph.D. Dissertation, Department of Agricultural Economics and Extension, Federal University of Technology, Akure, Nigeria).

Ogunsumi, L. O. (2010). Sustainability of agricultural technologies in Southwest, Nigeria: The case of cassava farmers. Journal of Agricultural Extension and rural Development, 2(7), 123-132.

Ogunsumi, L. O., Ajayi, A., Amire, C. M., \& Williams, S. (2013). Sustainability of Agricultural Transformation Agenda: The Place of Rice Farmers in Ogun State, Nigeria. Journal of Research on Humanities and Social Sciences, 3(13).

Osuntoyinbo, T. (1976). Rural Women in Agricultural Development: A Nigerian Case Study. Paper Presented at the Conference on Nigerian Women and Development, University of Ibadan, Ibadan.

Peason, R. (1996). Gender Matters in Development. Speakers Notes 9628 (pp. 1-25). International Seminars on Gender Matters in Development, April 23-May 2, 1996, Norwich. 
Rogers, B. (1984). Women and Rural Development in Nigeria: Critical Issues (pp. 1-55). ILO Geneva.

Spencer, S. C. D. (1976). African Women and Agricultural Development: A case Study in Sierra-Leone. OLC Paper No. 9 (pp. 1-35). Overseas Laison Committee America Council on Education.

Spiro, H. M. (1977). The Role of Women Farmers in Oyo State, Nigeria: A Case Study in Two Rural Communities. Agricultural Economic Discussion, Paper No. 7/80. IITA, Ibadan.

Mueller, E. (1978). Determination of the Intra-Household Allocation of Time (pp. 1-55). A Paper Presented at the Workshop on Women's Role and Demographic Change. Research Programme, Geneva.

Adeyeye, V. A. (1996). Gender and Rural Poverty (pp. 1-25). GAP Seminar Presentation, NISER, Ibadan.

\section{Copyrights}

Copyright for this article is retained by the author(s), with first publication rights granted to the journal.

This is an open-access article distributed under the terms and conditions of the Creative Commons Attribution license (http://creativecommons.org/licenses/by/4.0/). 